\title{
Granuloma faciale: a rare disease from a dermoscopy perspective*
}

\section{Granuloma facial: uma doença rara sob uma perspectiva dermatoscópica}

\author{
Danilo Augusto Teixeira ${ }^{1}$
}

Bruna Estrozi ${ }^{2}$

Mayra Ianhez ${ }^{3}$

DOI: $h$ ttp://dx.doi.org/10.1590/abd1806-4841.20132384

\begin{abstract}
The granuloma faciale is a rare and benign skin disease of unknown etiology, characterized by chronic leukocitoclastic vasculitis. It is characterized by skin lesions predominantly facial whose course is chronic and slowly progressive. The diagnosis is based on clinical features, histopathology and, more recently, in dermoscopy. We describe the case of a male patient, 40 years old, with a sarcoid lesion on the malar site, whose histopathological examination revealed a mixed inflammatory infiltrate with presence of Grenz zone. Dermoscopy revealed a pink background with white striations. The definitive diagnosis is made by histopathologic evaluation, and dermatoscopy can be helpful. It is known to be resistant to therapy, oral medications, intralesional and surgical procedures are options.

Keywords:Dermoscopy; Diagnosis;Diagnosis, differential; Eosinophilic granuloma; Facial dermatoses; Pathology

Resumo: O granuloma facial é doença cutânea rara e benigna, de etiologia desconhecida, caracterizado por vasculite leucocitoclástica crônica. Caracteriza-se por lesões cutâneas predominantemente faciais, tem curso crônico e lentamente progressivo. O diagnóstico é baseado na clínica, histopatologia e, mais recentemente, na dermatoscopia. Relatamos o quadro de um paciente masculino, 40 anos de idade, com lesão sarcoídea na face malar, cujo exame histopatológico revelou infiltrado inflamatório misto com presença de zona de Grenz. A dermatoscopia revelou um fundo rosado com estrias brancas. O diagnóstico definitivo é feito pela avaliação histopatológica, sendo que a dermatoscopia pode ser útil. É conhecida por ser resistente à terapêutica, sendo propostas medicações orais, intralesionais e procedimentos cirúrgicos.

Palavras-chave: Dermatoses faciais; Dermoscopia; Diagnóstico; Diagnóstico diferencial; Granuloma eosinófilo; Patologia
\end{abstract}

\section{INTRODUTION}

Granuloma faciale (GF) is a rare and benign skin disease characterized by chronic leukocytoclastic vasculitis with dense infiltration of polimorfonucleares. ${ }^{1,2}$ It is most common in males, typically in middleaged white individuals. ${ }^{1}$ Of unknown origin, it is characterized by predominantly facial skin lesions whose course is chronic and slowly progressive. ${ }^{3}$

Diagnosis is based on clinical features, histopathology and, more recently, dermatoscopy. ${ }^{1}$ Multiple modalities of medical and surgical treatment have been suggested, but none has proved to be consistently effective. ${ }^{4}$

The following report shows the importance of including GF in the differential diagnosis of face sarcoid lesions and analyses its dermoscopic features.

\section{CASE REPORT}

Male patient, 40 years old, referred an erythematous-edematous asymptomatic lesion in the right malar region for 4 years. He denied other skin lesions, systemic symptoms and comorbidities. He was using topical steroids (betamethasone dipropionate 0.05\% cream) and prednisone $60 \mathrm{mg} /$ day for 2 months. Physical examination showed erythematous plaque, infiltrated, on the right malar region, with prominent follicular orifices, assuming a "peau d'orange" appearance. (Figure 1).

The dermoscopic examination showed a pink background, with some areas blackened, white striations in different directions and prominent follicular orifices (Figure 2).

\footnotetext{
Received on 20.12.2012.

Approved by the Advisory Board and accepted for publication on 21.02.2013.

* Work performed at the Federal University of Goiás (UFG) - Goiânia (GO), Brazil.

Financial Support: None.

Conflict of Interests: None.

MD - Resident in the Department of Dermatology, Federal University of Goiás (UFG) - Goiânia (GO), Brazil.

Pathologist at the Pathology Consulting Service - Botucatu (SP), Brazil.

MSc in Dermatology, Federal University of São Paulo (UNIFESP) - Assistant Professor of Dermatology at the Federal University of Goiás (UFG) - Goiânia (GO), Brazil.

C2013 by Anais Brasileiros de Dermatologia
} 
Histopathological examination showed intense mixed inflammatory infiltrate of micronodular aspect, composed of lymphocytes, histiocytes, neutrophils and numerous eosinophils. The described infiltration had not reached the subepidermal region (Grenz zone) and there was no evidence of vasculitis (Figure 3). Immunohistochemistry suggested polyclonality $(\mathrm{CD} 3+, \mathrm{CD} 4+, \mathrm{CD} 8+, \mathrm{CD} 30+)$.

GF was diagnosed based on clinical examination, dermoscopy and histopathological aspects. Laboratory tests were within normal limits, and ANA (antinuclear factor), VDRL (Venereal Disease Research Laboratory) and smear lymph, negatives. Dapsone was prescribed $100 \mathrm{mg} /$ day. Intralesional corticosteroid and prednisone were suspended. The patient returned after nine months of treatment with partial improvement (Figure 4).

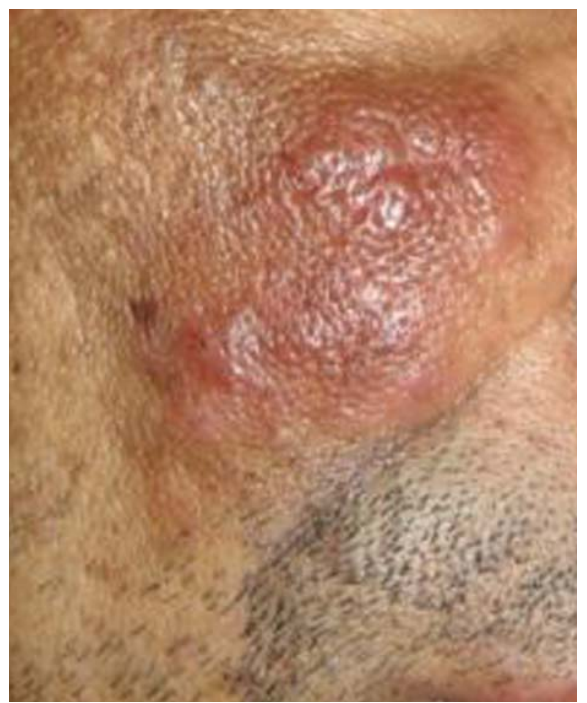

FIGURE 1:

Pretreatment. Erythematous plaque, infiltrated, on the right malar region, with prominent follicular orifices, with a "peau d'orange" aspect

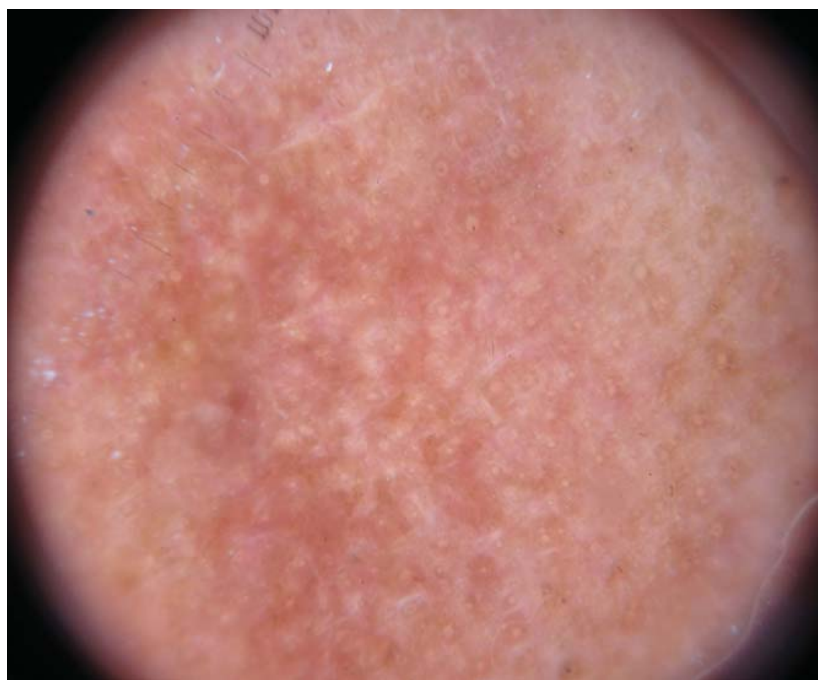

FIGURE 2: Dermoscopy. Pink background with some areas blackened, white striations in different directions and prominent follicular orifices

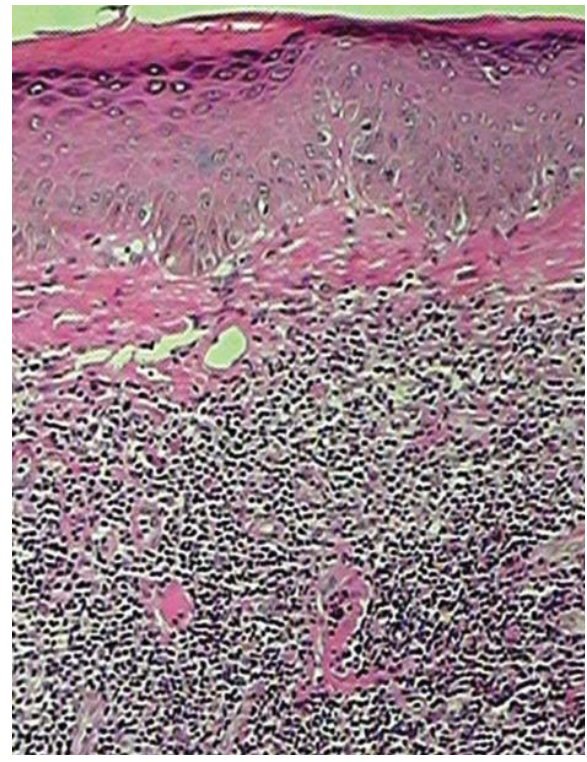

Figure 3: Histopathology. Intense mixed inflammatory infiltrate of micronodular aspect, preserving the subepidermal region (Grenz zone)

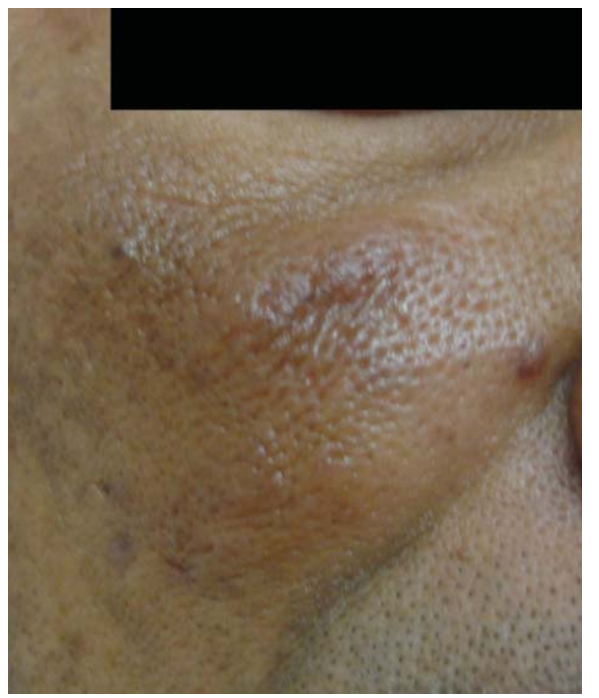

FiguRE 4:

Post treatment. Partial improvement on clinical aspect after nine months of treatment

\section{DISCUSSION}

The term GF was originally described by Wigley in 1945 as eosinophilic granuloma of the skin, and was further defined by Lever and Leeper Pinkus a few years later. ${ }^{4}$

Granuloma faciale has an unknown etiology, but possible predisposing factors include actinic exposure, radiation, trauma, allergy, or an Arthus-like reaction. ${ }^{5}$ It prevails between the third and fifth decade, with chronic course and exacerbation with sun and heat exposure. ${ }^{2}$

Clinically, GF manifests as papules, plaques or nodules, solitary or multiple, with no tendency to ulceration, whose color varies from red to violet. ${ }^{2,6}$ Superficial telangiectasias and follicular accentuation can often be observed, although normally its surface is smooth. ${ }^{1,4}$ Our case showed the typical "peau d'orange" appearance, exemplifying the follicular accentuation. 
The typical lesion is a solitary plaque on the face, as presented by our patient. The favored sites are the sides of the nose (30\%), tip of the nose $(7 \%)$, preauricular area $(22 \%)$, cheeks $(22 \%)$, forehead $(15 \%)$, and helix of the ear $(4 \%){ }^{6}$

Extrafacial involvement is rare and has been reported to involve the back, arms, chest, shoulders, and thigh. ${ }^{6}$ The lesions are generally asymptomatic, but some patients report associated burning and itching. ${ }^{4}$ GF is not associated with systemic involvement. The only extracutaneous lesion, whose association was described with facial granuloma, is eosinophilic angiocentric fibrosis, which affects the mouth and upper airways. ${ }^{3}$

The main clinical differential diagnoses include erythema elevatum diutinum, sarcoidosis, cutaneous lymphomas, lymphocytoma cutis, discoid lupus, basal cell carcinoma, lymphocytic infiltrate of Jessner, fixed drug eruption, lupus vulgaris, fungal and mycobacterial infections. ${ }^{1,2,4,6}$ Despite the appearance of the skin, GF rarely causes difficulties in the histopathological differentiation of mycosis fungoides or other types of lymphomas due to the lack of involvement of the epidermis and the polyclonal infiltrate, as shown in our case. ${ }^{1}$

The only report of GF dermoscopy revealed translucent whitish-grayish structureless areas, intermingled with orthogonal whitish streaks and the presence of focused and elongated telangiectasias, similar to streaks identified in dermoscopy of the described case; the pink background, with follicular accentuation of the case, does match with the clinical appearance of "peau d'orange". ${ }^{1}$ The patient described above was elderly (72 years) and already had telangiectasias on the face. Clinically, GF may mimic cutaneous sarcoidosis, discoid lupus erythematosus and lupus vulgaris. ${ }^{1}$ Dermoscopy of these diseases shows similari- ties in some aspects (Chart 1). ${ }^{1,7-10}$ Definitive diagnosis is made by histological examination of the lesion.

Histopathologically, GF is characterized by the presence of an unaltered epidermis, which is separated from a zone of dermal inflammation by a grenz zone of uninvolved upper dermis. ${ }^{1,5}$ There is an intense infiltration of polymorph below the Grenz zone consisting of neutrophils, lymphocytes, histiocytes, eosinophils and histiocytes. ${ }^{1,5}$ The adnexal structures of the skin are spared. ${ }^{1}$ Vascular inflammation, including perivascular inflammation with nuclear dust, and damage in the vessel wall, are frequently observed, although it was not present in this case. Erythrocyte extravasation and hemosiderin deposition were found, which may have contributed to the color of the lesion. ${ }^{1}$

The laboratory evaluation was normal except for occasional mild blood eosinophilia. ${ }^{3}$

The disease is known to be notoriously resistant to therapy, although in some cases it can resolve spontaneously. ${ }^{4}$ Proposed treatment schemes include colchicine, dapsone, antimalarials, gold injections, isoniazid, clofazimine, associated with psoralen ultraviolet radiation (PUVA), topical and intralesional corticosteroids and, more recently, topical tacrolimus. ${ }^{4} \mathrm{~A}$ variety of surgical procedures such as surgical excision with or without grafting, dermabrasion, laser argon, carbon dioxide laser, pulsed dye laser, electrosurgery and cryotherapy have also been used in the management of GF with varying results. ${ }^{4,6}$

The use of topical tacrolimus has recently been demonstrated as a safe and effective option. This immunomodulatory agent inactivates calcineurin leading to blockage of $\mathrm{T}$ cell activation and inhibition of interferon secretion. ${ }^{1}$

Among the treatments available, we chose dapsone and intralesional corticosteroids. Therapeutic

CHART 1: Dermoscopic aspect of GF and its differential diagnoses

\begin{tabular}{|ll|}
\hline Disease & Dermoscopic aspects \\
\hline Cutaneous sarcoidosis & A translucent white-gray background intermingled \\
Lupus vulgaris & Trith whitish streaks and elongated telangiectasias. ${ }^{1}$ \\
& Fine focused telangiectasias on a typical yellow to gold-colored background. In addition, some milia- \\
Discoid lupus erythematosus & like cysts and whitish reticular streaks are observed. ${ }^{8}$ \\
Basal cell carcinoma & Erythema, keratin plugs and pigmentary changes are variably present. ${ }^{9}$ \\
& Different patterns: arborizing telangiectasias, multiple blue-gray globules, large blue-gray ovoid \\
& nests, leaflike areas, spoke wheel areas and erosion or ulceration. ${ }^{10}$
\end{tabular}


response was partial improvement, consistent with the data found in the literature.

This case demonstrates the importance of including GF between the clinical differential diagnosis of sarcoid lesions of the face and describes the usefulness of dermoscopy as a further tool for identification and differentiation. $\square$

\section{REFERENCES}

1. Caldarola G, Zalaudek I, Argenziano G, Bisceglia M, Pellicano R. Granuloma faciale: a case report on long-term treatment with topical tacrolimus and dermatoscopic aspects. Dermatol Ther. 2011;24:508-11.

2. Ito LM, Barros JF, Andrade R, Neves SRC. Granuloma faciale: case study. An Bras Dermatol. 1999;74:245-7.

3. Marcoval J, Moreno A, Peyr J. Granuloma faciale: a clinicopathological study of 11 cases. J Am Acad Dermatol. 2004;51:269-73.

4. Ludwig E, Allam JP, Bieber T, Novak N. New treatment modalities for granuloma faciale. Br J Dermatol. 2003;149:634-7.

5. Thiyanaratnam J, Doherty SD, Krishnan B, Hsu S. Granuloma faciale: case report and review. Dermatol Online J. 2009;15:3.

6. Nasiri S, Rahimi H, Farnaghi A, Asadi-Kani Z. Granuloma faciale with disseminated extra facial lesions. Dermatol Online J. 2010;16:5.

7. Pellicano R, Tiodorovic-Zivkovic D, Gourhant JY, Catricalà C, Ferrara G, Caldarola G, et al. Dermoscopy of cutaneous sarcoidosis. Dermatology. 2010;221:51-4.

8. Brasiello M, Zalaudek I, Ferrara G, Gourhant JY, Capoluongo P, Roma P, et al. Lupus vulgaris: a new look at an old symptom - the lupoma observed with dermoscopy. Dermatology. 2009;218:172-4.

9. Lopez-Tintos B0, Garcia-Hidalgo L, Orozco-Topete R. Dermoscopy in active discoid lupus. Arch Dermatol. 2009;145:358.

10. Sanchez-Martin J, Vazquez-Lopez F, Perez-Oliva N, Argenziano G. Dermoscopy of small basal cell carcinoma: study of 100 lesions $5 \mathrm{~mm}$ or less in diameter. Dermatol Surg. 2012;38: 947-50.

MAILING ADDRESS:

Danilo Augusto Teixeira

Rua C 154, Quadra 326, Lote 5 n 45- Jardim América

74275-140 - Goiânia - GO

Brazil

E-mail: danilodermato@yahoo.com.br

How to cite this article: Teixeira DA, Estrozi B, Ianhez M. Granuloma faciale: a rare disease from a dermoscopy perspective. An Bras Dermatol. 2013;88(6 Suppl 1):S97-100. 